A Natural History of Shells 



\section{A Natural History of}

SHELLS

BY

Geerat J. Vermeij

With a new preface by the author

PRINCETON UNIVERSITY PRESS

PRINCETON AND OXFORD 
Copyright ( 1993 by Princeton University Press

Preface to the new paperback edition, copyright (C) 2021

by Princeton University Press

Published by Princeton University Press, 41 William Street,

Princeton, New Jersey 08540

In the United Kingdom: Princeton University Press,

6 Oxford Street, Woodstock, Oxfordshire OX20 1TR

press.princeton.edu

All Rights Reserved

First published by Princeton University Press in 1993

New Princeton Science Library paperback, with a new preface by the author, 2021

Paperback ISBN 978-0-691-22924-9

Library of Congress Control Number: 2021934445

This book has been composed in Adobe Baskerville with Avant Garde display Text designed by Jan Lilly

Cover image: iStock

Printed in the United States of America 